\title{
Pengaruh Sari Seduh Teh Hitam (Camelia sinensis) Terhadap Penghambatan PPAR $\gamma$ Sel Adiposa Jaringan Lemak Visera Rattus norvegicus strain Wistar
}

\author{
Elan Herlina ${ }^{1}$, Fatchiyah ${ }^{1}$, Rasjad Indra ${ }^{2}$ \\ ${ }^{1}$ Jurusan Biologi, Fakultas Matematika dan Ilmu Pengetahuan Alam Universitas Brawijaya \\ ${ }^{2}$ Jurusan Pendidikan Dokter, Fakultas Kedokteran, Universitas Brawijaya \\ alamat korespondensi: ikakelan@yahoo.co.id
}

\begin{abstract}
ABSTRAK
Penelitian bertujuan mengetahui pengaruh sari seduh teh hitam terhadap pengekspresian PPAR ã sel adiposa jaringan lemak visera Rattus norvegicus strain Wistar. Duabelas ekor tikus (Rattus norvegicus strain Wistar) jantan umur 6-8 minggu, berat 200 gram, diberi 4 macam perlakuan, yaitu A (diet tinggi lemak + SSTH 0 g/hari), B (diet tinggi lemak + SSTH $0,015 \mathrm{~g} / \mathrm{hari}$ ), $\mathrm{C}$ (diet tinggi lemak + SSTH 0,030 g/hari) dan D (diet tinggi lemak + SSTH 0,045 g/hari) selama 90 hari. Setelah masa perlakuan, tikus dibedah dan diambil lemak viseranya. Jaringan tersebut kemudian dibuat preparat dengan metode parafin. Jumlah sel yang mengekspresikan PPAR a dianalisis dengan menggunakan pewarnaan immunohistokimia dan untuk mengkonfirmasi bentuk sel adiposa digunakan pewarnaan Hematoxylene\&Eosin. Antibodi primer yang digunakan adalah anti PPAR gamma poliklonal antibody rabbit IgG dan antibodi sekunder biotin-goat-anti rabbit IgG. Hasil penelitian menunjukkan jumlah sel adiposa yang mengekspresikan PPAR ã mengalami penurunan seiring dengan penambahan dosis SSTH. Hal tersebut mengindikasikan SSTH dapat menurunkan pengekspresian PPAR $\tilde{a}$ pada sel adiposa jaringan lemak visera.
\end{abstract}

Kata kunci : jaringan lemak visera, PPAR a, diet tinggi lemak, sari seduh teh hitam

\section{Pendahuluan}

Jaringan adiposa merupakan salah satu jaringan penyambung yang terdiri dari sel-sel adiposa dan tersebar di seluruh tubuh. Sel-sel adiposa tersebut berperan sebagai mediator penting pada berbagai proses fisiologi dan pathologi yang berkaitan dengan metabolisme energi (Morrison dan Farmer, 2000). Distribusi sel-sel adiposa dalam tubuh dapat digunakan untuk memprediksi resiko kesehatan, terutama timbunan lemak di bagian intraabdominal atau visera. Jumlah lemak yang terdapat pada daerah tersebut sangat penting untuk menentukan gangguan yang terjadi pada metabolisme lemak dan glukosa (Elbers,dkk, 1997). Gangguan terhadap metabolisme tersebut menyebabkan berbagai penyakit, terutama obesitas (Morrison dan Farmer, 2000). Obesitas saat ini menjadi masalah kesehatan masyarakat di seluruh dunia, termasuk Indonesia. Obesit ${ }^{1}$ as telah menjadi suatu penyakit epidemi yang bersifat patogenik yang dapat memicu timbulnya penyakit kronis yang berkaitan dengan diet, seperti diabetes, penyakit kardiovaskular, hipertensi, stroke dan bentuk kanker tertentu (WHO, 2003).

Regulasi metabolisme lemak dan glukosa berperan penting dalam homeostatis energi dalam tubuh. Menurut Soeatmadji (2005) regulasi metabolisme lemak dan glukosa dalam tubuh melibatkan modulasi aktifitas berbagai protein. Hal itu dapat terlaksana dengan memodulasi kecepatan transkripsi oleh berbagai faktor transkripsi. Salah satu faktor transkripsi tersebut adalah Peroxisome proliferator-activated receptor (PPAR). Faktor transkripsi ini memegang peranan penting dalam berbagai fungsi selular termasuk metabolisme lemak, proliferasi sel, diferensiasi adipogenesis dan pensinyalan inflamatori (Sigma-aldrich, 2006). PPAR terdiri dari tiga subtipe, yaitu PPAR alfa, PPAR beta dan PPAR gamma. Subtipe PPAR yang berhubungan dengan regulasi perkembangan sel lemak adalah PPAR gamma (Medterms, 2006). Diet tinggi lemak memicu peningkatan jumlah asam lemak bebas dan peningkatan aktivasi PPAR gamma, sehingga menstimulasi penyimpanan lemak, adipogenesis dan 
obesitas (Croston, 2007).

Pada saat ini banyak dilakukan penelitian mengenai bioaktif yang terkandung dalam tanaman. Menurut Ostaszewski (2002), senyawa yang termasuk dalam bioaktif adalah polifenol, fitoestrogen, fitosterol, phytates dan poliunsaturated fatty acids. Sebagian besar senyawa tersebut merupakan antioksidan. Salah satu bahan alami alternatif yang berpotensi dalam terapi obesitas adalah penggunaan teh hitam $(\mathrm{Ca}$ mellia sinensis). Hal ini disebabkan oleh adanya komponen polifenolik, seperti teaflavin yang telah dilaporkan memiliki peranan dalam aktivitas biologi (Lee, 2004). Aktivitas antioksidan teaflavin yang terkandung dalam teh hitam lebih tinggi daripada senyawa polifenolik yang terkandung dalam teh hijau, yaitu catesin. Teaflavin banyak diteliti sebagai agen pelindung penyakit kardiovaskular dan kanker karena kemampuannya dalam bidang farmakimia, termasuk antihipertensi, antioksidatif, dan aktivitas hipolipidemik (Leung, dkk, 2001). Oleh karena itu, kemampuan komponen polifenolik yang terkandung dalam teh hitam diduga dapat mempengaruhi jumlah sel adiposa yang mengekspresikan pengekspresian PPAR gamma.

Berdasarkan latar belakang tersebut di atas, permasalahan yang dipecahkan dalam penelitian ini adalah apakah sari seduh teh hitam berpengaruh terhadap jumlah sel adiposa yang mengekspresikan PPAR gamma pada jaringan lemak visera Rattus norvegicus strain Wistar. Sedangkan tujuan dari penelitian ini adalah untuk untuk mengetahui pengaruh sari seduh teh hitam terhadap jumlah sel adiposa yang mengekspresikan PPAR gamma pada jaringan lemak visera Rattus norvegicus strain Wistar.

\section{Metode Penelitian \\ Waktu dan Tempat Penelitian}

Penelitian dilaksanakan pada bulan Juli 2006 - November 2007. Pemeliharaan dan pemberian perlakuan kepada hewan coba dilakukan di Laboratorium Farmakologi Fakultas Kedokteran Universitas Brawijaya Malang, sedangkan pewarnaan Hematoksilin-Eosin (H\&E) dan Imunohistokimia dilakukan di Laboratorium Patologi Klinik Faal Fakultas Kedokteran dan Laboratorium Biologi Molekuler,
Universitas Brawijaya Malang.

\section{Perlakuan Hewan Coba}

Hewan coba yang berjumlah 12 ekor dibagi menjadi empat kelompok perlakuan dan pembagian tersebut menggunakan rancangan acak lengkap. Rancangan ini memberikan peluang dalam mengukur pengaruh perlakuan pada kelompok eksperimen dengan cara membandingkan kelompok eksperimen dengan kelompok kontrol. Empat kelompok perlakuan meliputi Kelompok A (hanya diberikan diet tinggi lemak), Kelompok B (diet tinggi lemak + SSTH 0,015 gr/hari), Kelompok C (diet tinggi lemak + SSTH 0,03 gr/hari), Kelompok D (diet tinggi lemak+ SSTH $0,045 \mathrm{gr} / \mathrm{hari}$ ). Ulangan yang dilakukan untuk masing-masing kelompok adalah tiga kali. Sebelum perlakuan, dilakukan pengadaptasian tikus di laboratorium selama 7 hari dengan pemberian diet normal sebanyak 30,5 g/hari. Pembuatan pakan untuk diet normal ialah dengan mencampurkan PAR-S dan tepung terigu cap "Gunung Bromo" dengan total kadar lemak 9,73\%. Selanjutnya, tikus-tikus tersebut diberi perlakuan sesuai dengan kelompok perlakuan selama 90 hari.

SSTH dibuat dengan cara menyeduh 1 gram teh hitam dengan $100 \mathrm{~mL}$ air mendidih lalu didiamkan selama kurang lebih 15 menit, kemudian disaring dan diambil filtratnya. Untuk kelompok perlakuan B dengan dosis 0,015 gram/hari, pada hewan coba diberikan 1,5 mL SSTH, kelompok perlakuan $\mathrm{C}$ dengan dosis 0,03 gram/hari diberikan $3 \mathrm{~mL}$ SSTH, dan kelompok perlakuan D dengan dosis 0,045 gram/hari diberikan 4,5 mL SSTH. Pembuatan pakan tinggi lemak terdiri dari pencampuran PAR-S, tepung terigu cap "Gunung Bromo", kolesterol, asam cholat dan minyak babi dengan kadar lemak sebesar $30,10 \%$. Asupan pakan tikus untuk diet tinggi lemak kurang lebih 15,26 g/ hari. Pada akhir perlakuan, dilakukan pengambilan jaringan adiposa di bagian visera tikus perlakuan.

\section{Pewarnaan Hematoxylene\&Eosin dan Imunohistokimia Jaringan Adiposa Hewan Coba}

Jaringan adiposa tikus yang diperoleh kemudian direndam dalam PFA (paraformaldehyde) $4 \%$ dalam suhu $4^{\circ} \mathrm{C}$. 
Setelah itu, jaringan tersebut dicuci sebanyak dua kali menggunakan Phosphate Buffer Saline (PBS) masing-masing selama 15 menit dan dicuci kembali dengan PBS selama 30 menit. Selanjutnya, dilakukan perendaman dengan seri etanol $70 \%$ dan 90\% di suhu ruang dengan waktu 1 jam untuk setiap larutan. Untuk perendaman dengan etanol $100 \%$ dilakukan dua kali dengan waktu perendaman masing-masing 1 jam. Kemudian, jaringan tersebut direndam dalam xylol I dan xylol II. Lama perendaman setiap larutan xylol tersebut adalah 1 jam Langkah berikutnya adalah melakukan perendaman dalam parafin cair I selama 1 jam dan kemudian dilanjutkan dalam parafin cair II yang telah diisikan ke dalam kubus aluminium foil selama 1 jam pula. Perendaman dalam parafin I dan II dilakukan di dalam oven yang bersuhu $62^{\circ} \mathrm{C}$. Aluminium foil yang telah berisi parafin dan jaringan adiposa tersebut kemudian diletakkan di atas wadah yang telah berisi air dan es batu. Setelah parafin memadat, dilakukan pemotongan untuk mendapatkan sayatan parafin yang berukuran 4-5 ìm.

Sayatan parafin yang didapatkan dari perlakuan sebelumnya diletakkan dalam obyek gelas. Obyek gelas tersebut kemudian dimasukkan kedalam oven dengan suhu $40^{\circ} \mathrm{C}$ selama $10-12$ jam. Selanjutnya, obyek gelas tersebut direndam dalam xylene I selama 10 menit dan xylene II selama 5 menit. Preparat tersebut kemudian dicuci dengan etanol $100 \%, 90 \%$ dan $70 \%$, masing-masing selama 5 menit. Pencucian selanjutnya ialah dengan PBS selama 5 menit sebanyak tiga kali dan dicuci dengan air mengalir selama 5 menit. Preparat tersebut kemudian diberi pewarna hematoksilin selama 2 menit dan dicuci dengan air mengalir selama 2 menit. Setelah itu dilanjutkan dengan pewarnaan eosin selama 10 menit dan dicuci dengan air mengalir kembali selama 5 menit. Setelah itu dilakukan pencucian dengan etanol $70 \%$, etanol 90\%, etanol 100\% dan xylol. Selanjutnya preparat ditutup kover gelas dengan menggunakan enthelan. Preparat hasil pewarnaan ini digunakan sebagai kontrol.

Selain diwarnai dengan pewarna $\mathrm{H} \& \mathrm{E}$, sayatan parafin dari jaringan adiposa hewan coba dibuat preparat dengan metode pewarnaan imunohistokimia. Sayatan parafin diletakkan dalam obyek gelas yang kemudian direndam dalam xylene I selama 10 menit, dalam xylene II selama 5 menit, etanol $100 \%$ selama 5 menit, etanol $90 \%$ selama menit dan etanol $70 \%$ selama 5 menit. Setelah itu dilakukan pencucian dengan PBS sebanyak tiga kali, dengan waktu 5 menit untuk setiap pencucian. Selanjutnya preparat tersebut direndam dalam $10 \mathrm{mM}$ buffer sitrat $\mathrm{pH}$ 7,2-7,4 yang telah dipanaskan dalam suhu $70^{\circ} \mathrm{C}$ selama 5 menit dan dimasukkan dalam oven bersuhu $90^{\circ} \mathrm{C}$. Setelah 15 menit, dilakukan pendinginan dengan cara memberikan air dingin di luar wadah preparat. Kemudian dilakukan pencucian dengan PBS sebanyak tiga kali masing-masing selama 5 menit. Setelah itu, preparat dimasukkan ke dalam $0,3 \% \mathrm{H}_{2} \mathrm{O}_{2}$ di suhu ruang selama 15 menit. Kemudian dilakukan pencucian dengan PBS selama 10 menit hingga 3 kali pencucian. Selanjutnya, dilakukan bloking dengan 2\% susu skim selama 30 menit di suhu ruang dan diberi antibodi pertama yaitu anti PPAR gamma antibodi poliklonal rabbit IgG (Bio Vision) (1:200). Setelah semalam, preparat dicuci dengan PBS selama 5 menit dengan frekuensi pencucian sebanyak 3 kali. Kemudian, dilakukan pemberian antibodi kedua yaitu biotin-goat-antirabbit $\operatorname{Ig} G$ (1:500) selama 1 jam di suhu ruang. Setelah itu, dicuci kembali dengan PBS sebanyak 3 kali, masing-masing selama 5 menit. Langkah berikutnya adalah melakukan perendaman dengan streptavidin peroksidase selama 20 menit dalam suhu ruang. Selanjutnya, dilakukan pencucian kembali dengan PBS selama 5 menit, sebanyak 2 kali dan 1 kali selama 10 menit. Perlakuan selanjutnya ialah pewarnaan DAB $(3,3$ diaminobenzidinetetrahydrochloride) di bawah mikroskop Olympus BX2. Setelah dilakukan pewarnaan DAB, dilakukan pencucian PBS kembali sebanyak tiga kali selama 10 menit. Kemudian, preparat tersebut diberi counter stain dengan Meyer Hematoxylene selama 2 menit dan dilanjutkan dengan pencucian air mengalir selama 2 menit. Langkah selanjutnya ialah dilakukan perendaman dalam etanol $70 \%$ selama 2 menit, etanol $90 \%$ selama 2 menit, $100 \%$ etanol dua kali masing-masing selama 2 menit, xylene I selama 2 menit dan xylene II selama 2 menit. Selanjutnya, preparat diberi enthelan dan ditutup dengan kover gelas.

Preparat hasil pewarnaan $\mathrm{H} \& \mathrm{E}$ dan 
imunohistokimia, selanjutnya diamati dengan menggunakan mikroskop NIKON optiphot 21 dengan sistem Difference Interference Contrast yang dilengkapi dengan kamera digital yang telah terhubung dengan program AverTV sehingga dapat tervisualisasi melalui layar komputer.

\section{Penghitungan Persentase Sel Adiposa Jaringan Lemak Visera yang Mengekspresikan PPAR ã}

Pada penelitian ini dilakukan penghitungan persentase sel adiposa dari jaringan lemak visera yang mengekspresikan PPAR gamma (Hansen, dkk, 1998). Setiap perlakuan dilakukan dengan tiga kali ulangan. Dalam setiap ulangan dilakukan penghitungan sel adiposa yang mengekspresikan PPAR gamma pada tiga potongan jaringan. Di setiap jaringan ditentukan tiga lapang pandang, yaitu bagian atas, tengah dan bawah. Penghitungan sel tersebut dilakukan pada perbesaran 200x dengan mikroskop cahaya Olympus BX2. Hasil perhitungan sel tersebut kemudian dipersentasekan dengan jumlah sel keseluruhan yang terdapat dalam setiap lapang pandang. Hasil rata-rata persentase sel yang didapatkan kemudian ditabulasi dan dianalisis.

\section{Analisis Data}

Persentase sel adiposa visera yang mengekspresikan PPAR gamma pada setiap kelompok perlakuan dianalisis dengan one way ANOVA dan dilanjutkan dengan uji Tukey dalam program SPSS 12 untuk mendapatkan informasi mengenai beda nyata antar variasi dosis sari seduh teh hitam pada perlakuan.

\section{Hasil dan Pembahasan}

Persentase sel adiposa yang mengekspresikan PPAR gamma mengalami penurunan seiring dengan penambahan dosis SSTH (Gambar 1). Perhitungan tersebut diperoleh melalui perhitungan inti sel adiposa yang bewarna coklat dari hasil pewarnaan immunohistokimia (Gambar 2).

Pemberian SSTH 0,015 g/hari dapat menurunkan jumlah sel yang mengekspresikan PPAR gamma, akan tetapi dosis yang dapat memberikan efek penurunan secara maksimal adalah SSTH $0,030 \mathrm{~g} /$ hari. Sebab, pada penambahan dosis SSTH di atas 0,030 g/hari memberikan efek yang hampir sama dengan SSTH 0,030 g/ hari. Hal ini ditunjukkan dengan hasil uji statistik yang sama untuk SSTH 0,030 g/hari dengan SSTH 0,045 g/ hari. Penurunan persentase sel yang mengekspresikan PPAR gamma tersebut menunjukkan bahwa SSTH dapat menurunkan jumlah sel adiposa yang

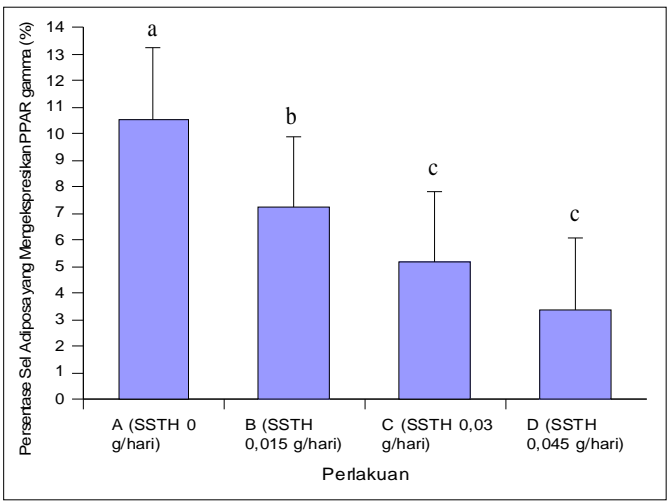

Gambar 1. Rasio sel lemak visera yang mengekspresikan PPAR ã pada tiap perlakuan $(\mathrm{P}<0,05)$

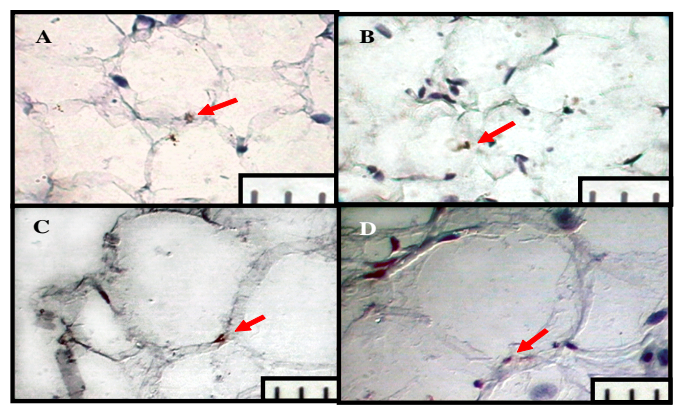

Gambar 2. Hasil pewarnaan immunohistokimia dengan antibodi anti PPAR $\gamma$

$$
\text { A : SSTH } 0 \mathrm{~g} / \text { hari; } \quad \text { B : SSTH } 0,015 \mathrm{~g} \text { /hari; }
$$$$
\text { C : SSTH 0,030 g/hari; } \quad \text { D : SSTH } 0,045 \mathrm{~g} / \text { hari; }
$$

$\longrightarrow$ : sel yang mengekspresikan PPAR $\gamma$;

1 skala : $0,01 \mathrm{~mm}$ (Perbesaran $400 \mathrm{x}$ )

mengekspresikan PPAR gamma pada jaringan lemak visera Rattus norvegicus strain Wistar.

TNF á dapat menginduksi pembentukan iNOS. Peningkatan iNOS menyebabkan peningkatan produksi NO yang dapat memicu kegagalan insulin dalam menstimulasi transport glukosa sehingga terjadi resistensi insulin. Resistensi insulin berarti ketidaksanggupan insulin memberi efek biologik yang normal pada kadar gula darah tertentu sehingga dibutuhkan kadar insulin yang lebih banyak untuk mencapai kadar glukosa darah yang normal (Merentek, 2006). PPAR gamma berperan dalam 


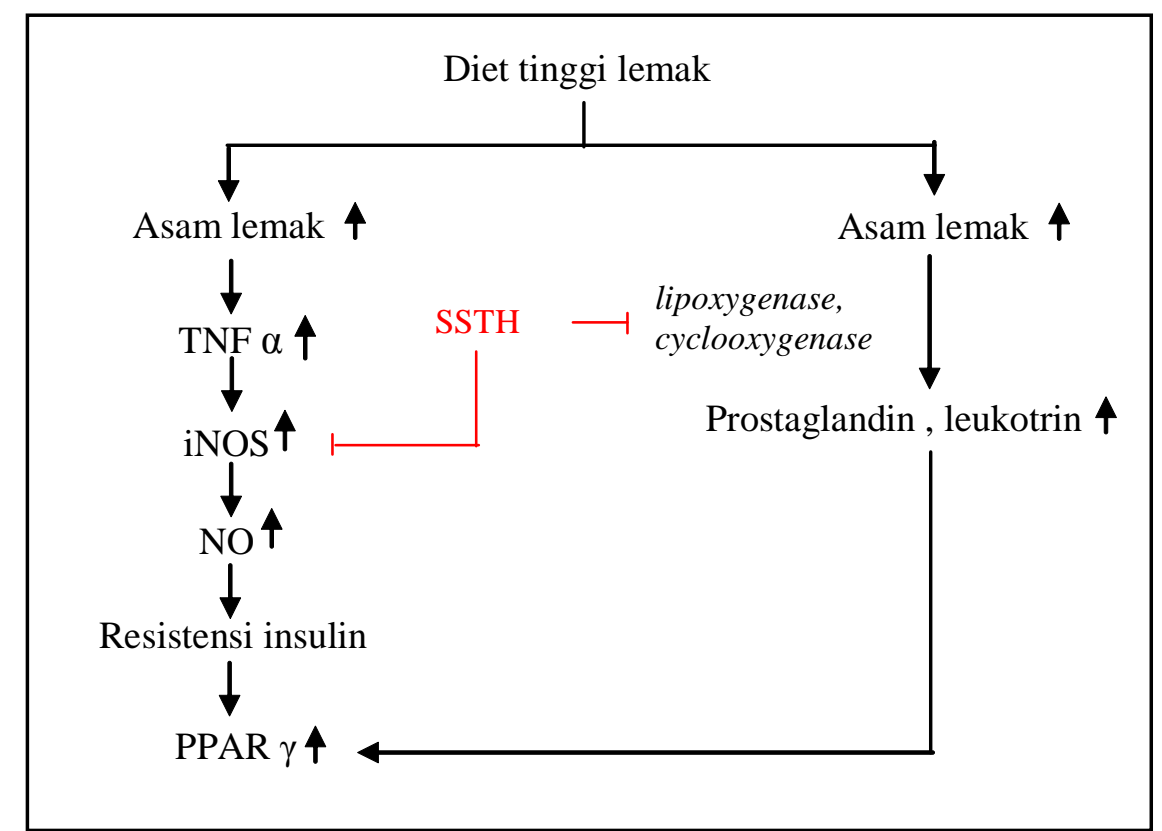

Gambar 3. Jalur penghambatan SSTH terhadap pengekspresian PPAR $\gamma$ pada sel adiposa

$$
\text { : Penghambatan oleh SSTH }
$$

penyimpanan asam lemak di dalam sel adiposa sehingga resistensi insulin menyebabkan peningkatan pengekspresian PPAR ã.

Semakin banyak PPAR gamma yang teraktivasi, maka asam lemak yang berlimpah di plasma dapat disimpan di dalam jaringan adiposa sehingga konsentrasi asam lemak di plasma berkurang (Soeatmadji, 2005). Oleh karena itu, apabila enzim iNOS dihambat, maka produksi NO akan menurun dan resistensi insulin akan menurun juga, sehingga pengekspresian PPAR gamma mengalami penurunan pula. Hal ini bersesuaian dengan hasil penelitian yang menunjukkan bahwa persentase sel yang mengekspresikan PPAR ã pada perlakuan tanpa SSTH lebih tinggi dibandingkan dengan perlakuan lain yang menggunakan SSTH (Gambar .3).

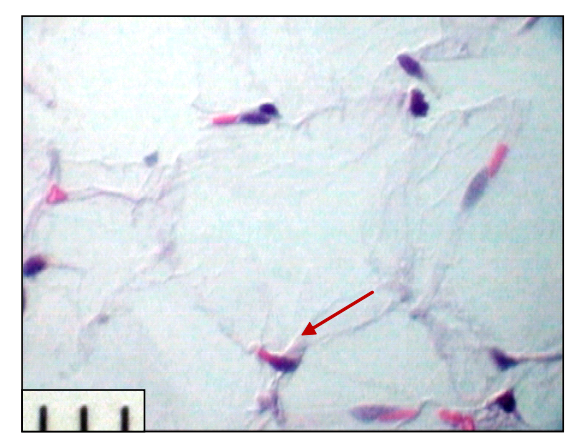

Gambar 4. Sel lemak visera Rattus norvegicus strain Wistar (Pewarnaan ematoxylene\&Eosin); 1 skala : 0,01 mm (Perbesaran 400x)
Sel lemak dari hasil visualisasi preparat yang diwarnai dengan Hematoxylene\&Eosin (Gambar 4) berbentuk bulat dengan inti yang terletak di tepi sehingga dapat diketahui jenis lemak tersebut, yaitu termasuk dalam golongan lemak unilokular. Pada bagian tengah sel berupa lumen yang merupakan vakuola lemak yang telah kosong, karena tetes lipid telah terlarut oleh alkohol dan xylol pada proses pembuatan preparat (Junqueira, dkk, 1998).

\section{Kesimpulan}

Persentase sel adiposa yang mengekspresikan PPAR gamma mengalami penurunan seiring peningkatan dosis SSTH. Hasil penelitian tersebut menunjukkan SSTH dapat menurunkan pengekspresian PPAR gamma sel adiposa jaringan lemak visera Rattus norvegicus strain Wistar.

\section{Daftar Pustaka}

Ahima RS and J.S. Filer. 2000. Adipose Tissue as An Endocrine Organ, Trends in Endocrine and Metab. 11:327-332.

Anonimous. 2007. Introduction to Immunohistochemistry. http:// www.ihcworld.com/. Tanggal Akses 6 Desember 2007.

Anonimous. 2007. The PPAR subfamily of nuclear receptors.http://www.jlr.org/. Tanggal Akses 30 November 2007. 
Camp, H.S., Tafuri, S.R., dan Leff, T. 1999. c-Jun N-Terminal Kinase Phosphorylates Peroxisome Proliferator-Activated Receptor- ã 1 and Negatively Regulates Its Transcriptional Activity. Endocrinology Vol. 140, No. $1392-$ 397.

Collins, R.D. 2007. Differential Diagnosis in Primary Care. Lippincott Williams \& Wilkins. ISBN: 0-7817-6812-8.

Croston, G. 2007. Role of PPAR ã Coactivators in Obesity and Thermogenesis. http://www.biocarta.com//. Tanggal Akses 28 November 2007.

Elbers, J. M.H., H. Asscheman., J.C. Seidell., J. A.J. Megens dan L.J.G. Gooren. 1997. Long- Term Testosterone Administration Increases Viseral fat in Female to Male Transsexuals. Journal of Clinical Endocrinology and Metabolism. http:// jcem.endojournals.org. Tanggal Akses 14 November 2006.

Frei, B dan J. V. Higdon. 2003. Antioxidant Activity of Tea Polyphenols In Vivo: Evidence from Animal Studies1. The Journal of Nutrition. American Society for Nutrition Sciences.

Fuller, G.M, dan D. Shields. 1998. Molecular Basis of Medical Cell Biology. Appleton \& Lange A Simon \& Schuster Company. Stamford. hal 176177.

Gartner, L. P., J. L. Hiatt., dan J.M. Strum. 2003. Cell Biology and Histology. 4 th Edition. Lippincott Williams\&Wilkins. Baltimore.

Gregoire, F.M. C.M. Smas, H.S. Sul. 1998. Understanding Adipocyte Differentiation. Physiological Reviews Vol. 78, USA. Hal 783-799.

Hansen, L.H., B. Madsen., B. Teisner., J.H. Nielsen., dan N. Billestrup. 1998. Characterization of the Inhibitory Effect of Growth Hormone on Primary Preadipocyte Differentiation. Molecular Endokrinology. 0888-8809

Hayat, MA. 2005. Handbook of Immunohistochemistry and in situ Hybridization of Human Carcinomas, Volume 3. Molecular Genetics, Liver carcinoma and Pancreatic Carcinoma. Elsevier Academic Press. Amsterdam. 432 hal.

Harmon, A.W. dan J. B. Harp. 2001. Differential effects of Flavonoids on 3T3$\mathrm{L} 1$ adipogenesis and lipolysis. Am $\mathrm{J}$
Physiol Cell Physiol 280: C807C813.

Heuvel, J.V. 2000. Basic Mechanism of Action of PPARa, PPARb(d) and PPARg and Effects on Gene Expression. http:/ /www.biocarta.com//. Tanggal akses 28 November 2007

Indra, M. R. 2005, Dasar Genetik Obesitas Viseral, dalam Buku Kumpulan Makalah Fourth Basic Molecular Biology Course in Pathophysiology of Obesity. Program Pascasarjana Universitas Brawijaya, Malang.

Indriyanti, R. S. 2005. Peran Asam Lemak Bebas, Stres Oksidatif dan Keadaan Inflamasi terhadap Kejadian Resistensi Insulin. Forum Diagnosticum edisi khusus 6/05. ISSN : 0854-7173.

Junqueira, L.C., J. Carneiro dan R.O. Kelley. 1997. Histologi Dasar. Penerbit Buku Kedokteran EGC. Jakarta. Halaman 123.

Kochan, Z. 2003. Adiponectin - the molecular link between obesity and diabetes, http://www.actabp.pl/pdf/Sup103/ Session13.pdf. Tanggal akses 10 Juni 2006.

Lee M. J, J. D. Lambert, S. Prabhu, X. Meng, H. Lu, P. Maliakal, C.T. Ho dan C. S. Yang, 2004, Delivery of Tea Polyphenols to the Oral Cavity by Green Tea Leaves and Black Tea Extract, Cancer Epidemiology, Biomarkers \& Prevention Journal Vol. 13.

Leung L. K, Y. Su, R. Chen, Z. Zhang, Y. Huang dan Z.Y. Chen, 2001, Theaflavins in Black Tea and Catechins in Green Tea Are Equally Effective Antioxidants, Biochemical and Molecular Action of Nutrients Research Communication Journal.

Levers, M. 2004. Lipoxygenase. http:// www.biochem.northwestern. edu/ holmgren/glossary/Definitions/DefL/lipoxygenase.html. Tanggal akses 30 November 2007.

Marin P, Andersson B, Ottosson M, Olbe L, Chowdhury B, Kvist H, Holm G, Sjostrom L, Bjorntorp, 1992, The Morphology and Metabolism of Intraabdominal Adipose Tissue in Men Metabolism. 41: 1242-1248.

Medterms,2006,Definition of PPAR, http:// www.medterms.com/ script/main/ art.asp?articlekey $=15502$, Tanggal 
akses 10 Juni 2006.

Merentek, E. 2006. Resistensi Insulin pada Diabetes Melitus Type II. Cermin Dunia Kedokteran No. 150.

Morrison, R.F. dan R.S. Farmer. 2000. Hormonal Signaling and Transcriptional Control of Adipocyte Differentiation. American Society for Nutritional Sciences. 130: 3116S-3121S.

Mutalib, P.K.S. 2003. Tinjauan Pustaka : Sintesis NO dan Sindrom CHAOS. Fakultas Kedokteran. Universitas Indonesia. Jakarta.

Ncl. 2000. Cyclooxygenase. http:// cancerweb.ncl.ac.uk/cgi-bin/ omd?lipoxygenase. Tanggal akses 30 November 2007.

Ostaszewski, P. 2002. Bioactive Substances of Plant Origin in Food - Impact on Genomics. http:// www.edpsciences.org/ articles/rnd/ pdf/2002/06/05.pdf. Tanggal Akses 14 Juli 2006.

Parton, L.E., F. Diraison., S.E. Neil., S.K. Ghosh., M. A. Rubino., J. E. Bisis., C. P. Briscoe dan G. A. Rutteri. 2004. Impact of PPAR gamma Overexpression and Activation on Pancreatic Islet Gene Expression Profile Analyzed with Oligonucleotida Microarrays. Am J Physiol Endocrinol Metab 287: E390-E404.

Patton, K.T. dan G.A. Thibodeu. 2000. Mosby's Handbook of Anatomy and Physiology. Mosby, Inc. Missouri. hal 30.

Ramos, V. 2005. Technical Aspects of Immunohistochemistry. Vet Pathol 42:405-426.

Rotondo, D. dan J. Davidson. 2002. Prostaglandin And PPAR Control of Immune Cell Function. Immunology Journal. Blackwell Science Ltd. 105(1): 20-22.

Sidwell. 2006. Immunocytochemistry. http:/ /www.sidwell.edu /us/science/21bio/ new/ thigmo_immuno.htm. Tanggal akses 26 Juni 2006.

Sigma-aldrich. 2006. PPAR Agonists. http:/ /www.sigmaaldrich. $\mathrm{com} /$ Area_of_Interest/Life_Science/ Cell_Signaling/Scientific_Resources/ PPARagonists. Tanggal akses 10 Juni 2006.

Soeatmadji, D. W, 2005.The Role of PPARs in The Homeostasis of Energy Balance, dalam Buku Kumpulan Makalah Fourth Basic Molecular Biology Course in Pathophysiology of Obesity. Program Pascasarjana Universitas Brawijaya, Malang.

Wacjenberg, B.L. 2000. Subcutaneous and Viseral Adipose Tissue: Their Relation to The Metabolic Syndrome. Endocrine Reviews 21(6)=697-738. http://edrv.endojournals.org//. Tanggal Akses 22 Desember 2005.

WHO.2003.Obesity and Overweight. www. who.int/hpr/NPH/docs/ gsobesity. pdf, Tanggal akses 10 Juni 2006

Wikipedia. 2007. Prostaglandin. http:// en.wikipedia.org/wiki/ Prostaglandin. Tanggal akses 30 November 2007.

Yashushi, S. 2005. Treatment of Obesity With Viscera Fat Accumulation. Clinic All Round Journal. Z0697A. IS SN:0371-1900. vol.54, no.4, Halaman 1378-1382.

Young, B. and J.W. Heath. 2000. Lab 2: Characterization of skin using immunohistochemistry, http:// outreach.mcb.harvard.edu/ down10 a d s / S u m me r $03 /$

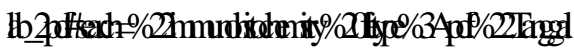
akses 9 Oktober 2006.

Zang, M., S. Xu., K.A.M. Toolan., A. Zuccalo., X. Hou., B. Jiang., M.Wierzbicki., T.J. Verbeuren dan R.A. Cohen. 2006. The American Diabetes Association. Vol 5. DOI : 10.2337/db05-1188. 